\title{
Transformation of Malaysian Construction Industry with Building Information Modelling (BIM)
}

\author{
Aryani Ahmad Latiffi ${ }^{1}$ Juliana Brahim ${ }^{2}$ and Mohamad Syazli Fathi ${ }^{3}$ \\ 1,2 Faculty of Technology Management \& Business, Universiti Tun Hussein Onn Malaysia (UTHM), 86400 Parit Raja, Batu Pahat, \\ Johor, Malaysia \\ ${ }^{3}$ UTM Razak School of Engineering and Advanced Technology, Universiti Teknologi Malaysia, 54100 Kuala Lumpur, Malaysia
}

\begin{abstract}
Building Information Modelling (BIM) is a revolution of technology and a process that transformed the way building is planned, designed, analysed, constructed and managed. The revolution of technology and process could increase the quality of construction projects. The knowledge of BIM has been expanding in many countries including Malaysia. Since its inception, the use of BIM has broadened up widely with different purposes. The aims of this paper is to investigate the BIM implementation and uses in Malaysian construction projects. The methodologies adopted for structuring this paper are by using literature review and semi-structured interview with construction players that have experienced and being involved in projects using BIM. The purpose of literature review is to illustrate on the pervious research on the subject matter. Meanwhile, the purpose of interviews is to explore the involvement of construction players, years of experience in projects using BIM and BIM uses in construction projects. The findings revealed that BIM has been implemented in Malaysia since 2007 by various construction players, which are client, architect, $\mathrm{C} \& \mathrm{~S}$ engineer, M\&E engineer, QS, contractor, facilities manager and BIM consultant. The findings also revealed that BIM is used for project' visualisation, improving project design, detecting design clashes, quantity take off and operation and maintenance. Further work will be focused on the current practices of construction players in projects using BIM.
\end{abstract}

\section{Introduction}

Building Information Modelling (BIM) is defined as an innovative way for approaching the design, construction and operation and maintenance of building [1]. It is a collaborative tool that used by Architectural, Engineering and Construction (AEC) industry $[2,3]$ that enhance visualisation and constructability of design, reduce time, cost as well as reduce conflict among construction players [3,4-6]. Since the inception of BIM, it is being increasingly implemented in the construction industry in order to produce data rich models of buildings and structural [3,7-9].

BIM is said as a project and process simulation $[3,5,10]$. This is because the realisation of BIM is much similar to the planning and actual of construction projects. Therefore, BIM could not be treated as an isolation of a software tool. It must gives impact on all the processes within the construction projects [6]. In addition to that, BIM helps by having projects simulation as it could shows the actual performance that happens in construction projects. This has made BIM as an efficient and effective tool in construction projects. With accurate building model, it allows smoother and better planned construction process that helps to reduce any errors and conflicts.
In the past decades, there had been a growing interest to adopt BIM in construction projects due to many benefits and resource saving during design, construction and maintenance and operation of project [11]. As a result, BIM has been implemented widely in the United State of America (USA), Australia, Hong Kong, Denmark, Norway, Finland and Singapore [2,7,12]. Compared to other developed countries, the implementation of BIM in Malaysia is very little and stagnant [13]. Moreover, there is a lack of evidence to show the involvement of construction players in projects using BIM. Therefore, this paper is seek to investigate on the transformation of Malaysian construction industry with BIM.

The next session discusses on the literature review on BIM in the Malaysian construction industry.

\section{Literature Review on BIM in the Malaysian Construction Industry}

Looking to the future is vital as the construction industry today is at the cross road of change [14]. The use of new technology in the construction industry could help the construction industry to face new challenges in construction such as managing a large amount of 2D

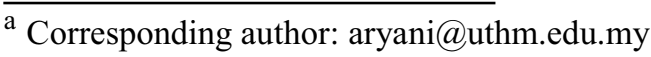


project documents, involvement of various construction players, discrepancies in project design $[15,16]$ and slow decision making [14]. Therefore, the use of new technology is needed for improving construction project from planning, design, construction as well as maintenance and operation of building. The implementation of a few past and mega projects in Malaysia such as Kuala Lumpur International Airport (KLIA), the second Penang Bridge, and monorail projects is the example of projects that need adaptation of new technology [17]. The adoption of new technology is needed to improve current practices in Malaysian construction industry that causes problems such as quality deficiencies, low productivity and catastrophes [17] that happened such as the collapse of Sultan Mizan Zainal Abidin Stadium in Kuala Terengganu [18].

There are many initiatives made by the Malaysian's government to encourage construction players to use BIM in projects to overcome the current problems. BIM has been introduced and implemented among construction players in Malaysia for the purpose of improving current construction projects. It has been introduced by Public Work Department (PWD) since early 2007 [2,4]. Furthermore, during the Second Day of Conference of Infrastructure and Construction Asia's Building Information Modelling and Sustainable Architecture 2009, the Director of PWD has urged the construction industry a need to embrace BIM in the construction project delivery [19]. This is followed by the first government project that used BIM in 2010 which is
National Cancer Institute (NCI) [20]. Further to that, BIM has been part of the agenda in Construction Industry Transformation Plan (CITP) 2016-2020 by adoption of modern construction method and technologies to address challenges in the industry [21].

PWD has formed BIM Unit Projects on May 2012 by Complex Management Division or known as PROKOM. It consists of involvement of architects, civil and structural (C\&S) engineers, mechanical and electrical (M\&E) engineers as well as quantity surveyors (QS). The purpose of BIM Unit Projects is to produce Revit Families that will be used through the building life cycle (22). Further to that, PWD has published first BIM guideline for projects using BIM [22]. However, the guideline is only use for in-house project done by PWD and still in refining process [22]. Previously, PWD has done their initial BIM projects which are Primary School of Meru Raya, at Ipoh, Perak and Primary School of Tanjung Minyak at Melaka. Currently, PWD has involved in their projects using BIM which are Administration Complex of Suruhanjaya Pencegah Rasuah Malaysia (SPRM) at Shah Alam, Selangor and Healthcare Centre Type 5 at Maran, Pahang.

PWD BIM guideline has established BIM uses as a guideline for projects using BIM. Each of the uses is determined by project' client to achieve the objective of using BIM in projects [22]. Figure 1 shows BIM uses along the project life cycle.

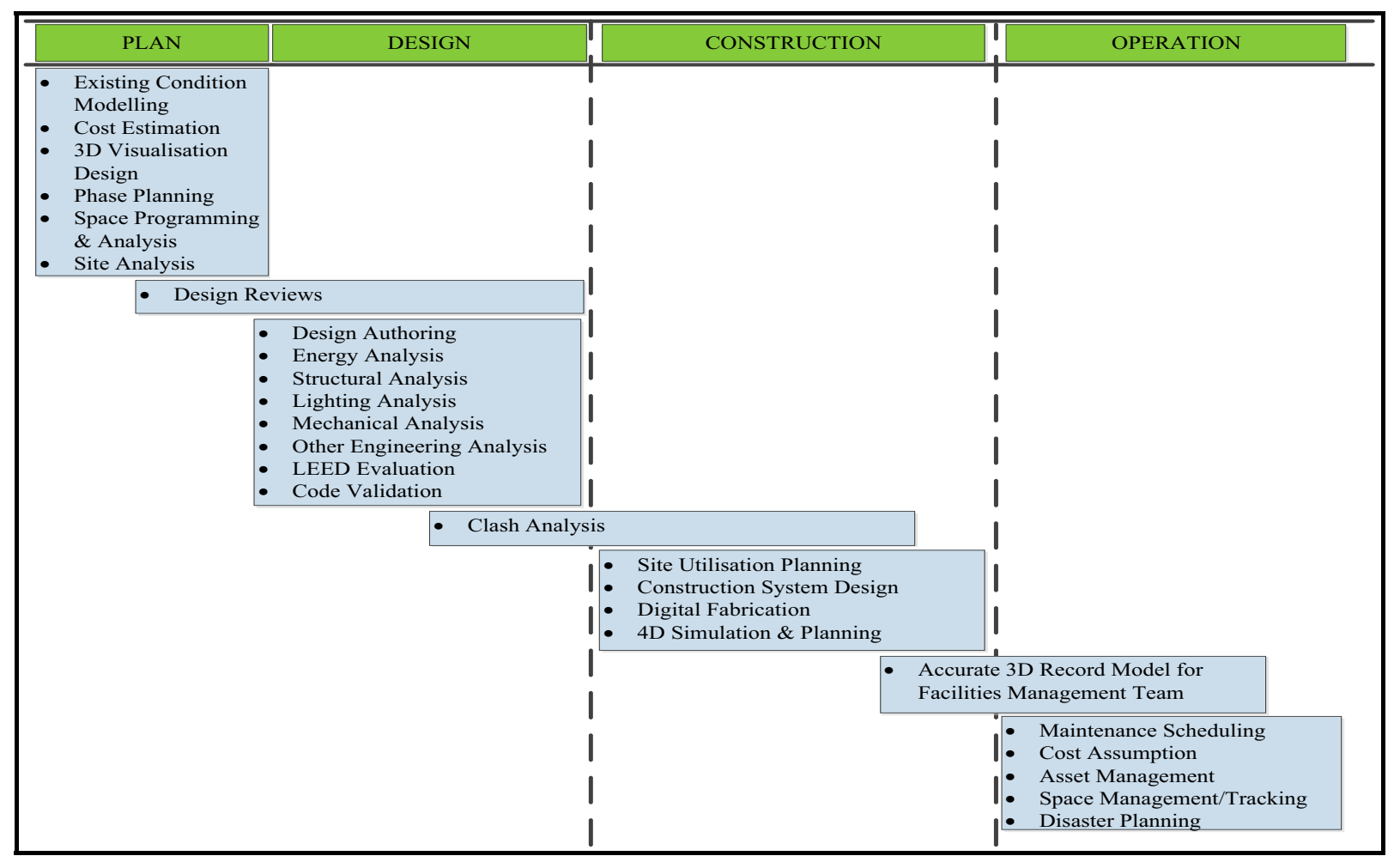

Figure 1. BIM Uses in Construction Project [22]

Based on the figure above, BIM is used in the early phase of construction until the final phase. The phases are plan, design, construction and operation. Plan and design phases are also known as pre-construction phase [3].
Meanwhile, the activities in operation phase is similar with post-construction phase [3]. Compared to conventional practices, the activities in projects using BIM mostly could be done in pre-construction phase 
$[3,15,16]$. By using BIM, it helps construction players to visualise and predict any potential problems such as design clashes before the construction takes place. This could help to save time and cost of projects as well as the quality of project could be improved.

When all the potential problems has been detected at early phase, the construction players could perform the construction activities smoothly without any clashes of activities, destruction such as rework due to design clashes and delay in delivering Request For Information (RFI) $[3,16]$. During construction phase, BIM is used to do simulation of sequence of work activities [3]. Other than that, BIM also helps to generate shops drawing for various building [3,15]. The use of BIM also helps to increase the quality of information regarding the facilities in the post-construction phase [15,24]. The information of facilities could help for future analysis of facilities, assets tracking, maintenance schedule and renovation in future [3]. Initially, PWD will use BIM partly in planning and design stage. The activities consisting of existing condition modelling, site analysis, programming, structural analysis, design authoring, design review, 3D coordination, cost estimation, phase planning and record modelling [22].

The next session will discuss on the methodology used to achieve the aim of this paper.

\section{Methodology}

Data for this paper is gained through a literature review and semi-structured interview. Both methods are used to gather information regarding BIM implementation in the Malaysian construction industry with its uses. A literature review was conducted to explore on the BIM implementation in the Malaysian construction industry. The information was gathered from books, journals articles, international conference papers and materials available on the internet.

In addition to that, semi-structured interview has been utilised with construction players that have experienced and who are currently involved in projects using BIM. List of respondents is gathered from the list of participants in seminars and series of BIM forum conducted by the Construction Industry Development Board of Malaysia (CIDB) in 2013 until 2014. From the list, a snowballing sampling have been conducted to access on the information of other potential respondent through the respondent gathered from the CIDB list. Snowballing sampling is used to get an access on 'hidden population' [25]. It is suitable for this research as not all the construction players that involved in project using BIM are participating in the seminar or event related to BIM organised by CIDB. Therefore, this technique is used as an assistant in enriching sampling size and for accessing new potential respondent.

Furthermore, semi-structured interviews were conducted to gain information on the involvement of various construction players in projects using BIM, their experience in projects using BIM and BIM uses in construction projects. One-to-one and face to face semistructured interviews were done with the respondents. A total of 28 respondents from the public and private sectors have been interviewed. The respondents are client, architect, civil and structure (C\&S) engineer, mechanical and electrical (M\&E) engineer, quantity surveyor (QS), contractor, facilities manager and BIM consultant. Those respondents were selected due to their willingness to share their experience and expertise in projects using BIM.

To obtain information on transformation of BIM in the Malaysian construction industry, a set of interview question was developed. The interview questions consist of two (2) sections as below:

Table 1. Interview Question

\begin{tabular}{|l|l|}
\hline \multicolumn{1}{|c|}{ Section } & \multicolumn{1}{|c|}{ Purpose } \\
\hline $\begin{array}{l}\text { Section 1: } \\
\text { Respondents' } \\
\text { Background }\end{array}$ & $\begin{array}{l}\text { To get an explicit of respondents' } \\
\text { information regarding years of } \\
\text { experience in the construction } \\
\text { industry. } \\
\text { To identify respondents' designation } \\
\text { in current involvement in project } \\
\text { using BIM. }\end{array}$ \\
\hline $\begin{array}{l}\text { Section 2: } \\
\text { Current } \\
\text { Practices of } \\
\text { BIM }\end{array}$ & $\begin{array}{l}\text { To identify the inception of BIM in } \\
\text { Malaysian construction industry. } \\
\text { To gain information on the use of } \\
\text { BIM in construction project. }\end{array}$ \\
\hline
\end{tabular}

Data collected were analysed by using content analysis technique. Content analysis is relevant to be used for analysing unstructured data such transcription of semi-structured interview. All data gained from the respondents then were analysed using Atlas t.i.7. Atlas.t.i. enable to analyse visual and hierarchical modelling of concepts and theory [26]. It merged with large amount of documents and keep the data in all fields that require close study and analysis of primary material consisting audio, images, codes, video and geo data. The benefit of this tool is to support content analysis and provide single location for a storage system, assisting in the establishment of rules of coding [26]. All data is represented in the form of table.

The next session will discuss on findings and discussion of data collected.

\section{Findings and Discussion}

This section discusses on data gained from the semistructured interview. The purpose of this section is to discuss on BIM implementation and its uses in Malaysian construction industry. This section consists of 4 sections as follows:

\subsection{Respondents' Designation}

The findings of respondents' designation is important to identify the construction players' involvement in projects using BIM in the Malaysian construction industry. There were 28 respondents from various designation involved with the interviews. Those respondents were selected based on their involvement and experience in projects 
using BIM in the industry. Table 2 shows the respondents' designation in projects using BIM.

Table 2. Respondents' Designation

\begin{tabular}{|c|c|c|c|c|c|c|c|c|}
\hline \multirow[b]{2}{*}{ Respondent } & \multicolumn{8}{|c|}{ Designation } \\
\hline & Client & Architect & \begin{tabular}{|c|} 
Civil t \\
Structure \\
Engineer
\end{tabular} & $\begin{array}{c}\text { MttE } \\
\text { Engineer }\end{array}$ & QS & Contractor & $\begin{array}{l}\text { Facilities } \\
\text { Manager }\end{array}$ & $\begin{array}{c}\text { Bim } \\
\text { Consultant }\end{array}$ \\
\hline $\mathrm{R}$ i & & & & & & & & 7 \\
\hline $\mathrm{R} 2$ & & & & & & I & & \\
\hline $\mathrm{R} 3$ & & & I & & & & & \\
\hline $\mathrm{Ri4}$ & & & I & & & & & \\
\hline Ri5 & & & & & & & & l \\
\hline Ri6 & & & & & I & & & \\
\hline $\mathrm{R} 7$ & & & & & & 7 & & \\
\hline Fi8 & & & & & & 1 & & \\
\hline Ri9 & & I & & & & & & \\
\hline $\mathrm{R} 10$ & & & & 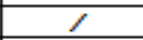 & & & & \\
\hline Ri11 & & & & & & & I & \\
\hline Ri12 & & & & & & & 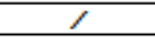 & \\
\hline Ri3 & & I & & & & & & \\
\hline Fi14 & & 1 & & & & & & \\
\hline Fi15 & & & $/$ & & & & & \\
\hline Ri16 & & & & I & & & & \\
\hline Ri17 & & & & & & I & & \\
\hline $\mathrm{R} 18$ & I & & & & & & & \\
\hline Ri19 & & & & 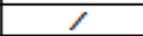 & & & & \\
\hline Ri20 & & & & & & & & 7 \\
\hline $\mathrm{F} 21$ & & & & & & & & I \\
\hline $\mathrm{R} 22$ & & & I & & & & & \\
\hline $\mathrm{Ri23}$ & & & & & & & & 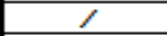 \\
\hline $\mathrm{Ri24}$ & & 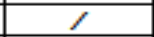 & & & & & & \\
\hline Ri25 & & & & I & & & & \\
\hline $\mathrm{R} 26$ & & & & 7 & & & & \\
\hline $\mathrm{R} 27$ & I & & & & & & & \\
\hline $\mathrm{R} 28$ & & & & 1 & & & & \\
\hline TOTAL & 2 & 4 & 4 & 6 & 1 & 4 & 2 & 5 \\
\hline
\end{tabular}

From the table, the indicator of R1 to R28 is used to represent each of respondent. The respondents are client, architect, $\mathrm{C} \& \mathrm{~S}$ engineer, $\mathrm{M} \& \mathrm{E}$ engineer, $\mathrm{QS}$, contractor, facilities manager and BIM consultant. Only two (2) respondents (R18, R27) were involved in projects using BIM as a client. Meanwhile, four (4) respondents (R9, R13, R14, R24) are architect and four (4) respondents (R3, R4, R15, R22) are C\&S engineer. On the other hand, six (6) respondents (R10, R16, R19, R25, R26, R28) that involved in projects using BIM are as a $\mathrm{M} \& \mathrm{E}$ engineer. Only 1 respondent (R6) involved as a QS in projects using BIM. Added to that, four (4) respondents (R2, R7, $\mathrm{R} 8, \mathrm{R} 17)$ are contractor in projects using BIM and two (2) respondents (R11, R12) involved as a facilities manager in projects using BIM. Despite of that, BIM consultant also involved in projects using BIM. BIM consultant is a person that being hired by company that has no experience in projects using BIM to assist on BIM strategies, design team and process of BIM implementation [27]. Five (5) respondents (R1, R5, R20,
$\mathrm{R} 21, \mathrm{R} 23)$ were involved in projects using BIM as a BIM consultant.

From the involvement of respondents in projects using BIM, the years of experience of each respondents has been determined to identify the inception of BIM implementation in the Malaysian construction industry. The next section will discuss on the respondents' experience in construction industry and projects using BIM.

\subsection{Respondents Experience in Project Using BIM}

Each of respondents are having different experiences and involvement in construction projects and projects using BIM. The aim of this paper is to identify the inception of BIM in Malaysian construction industry. Table 3 shows respondents' experiences in construction projects and projects using BIM. 
Table 3. Respondents' Experience in the Construction Industry and Projects Using BIM

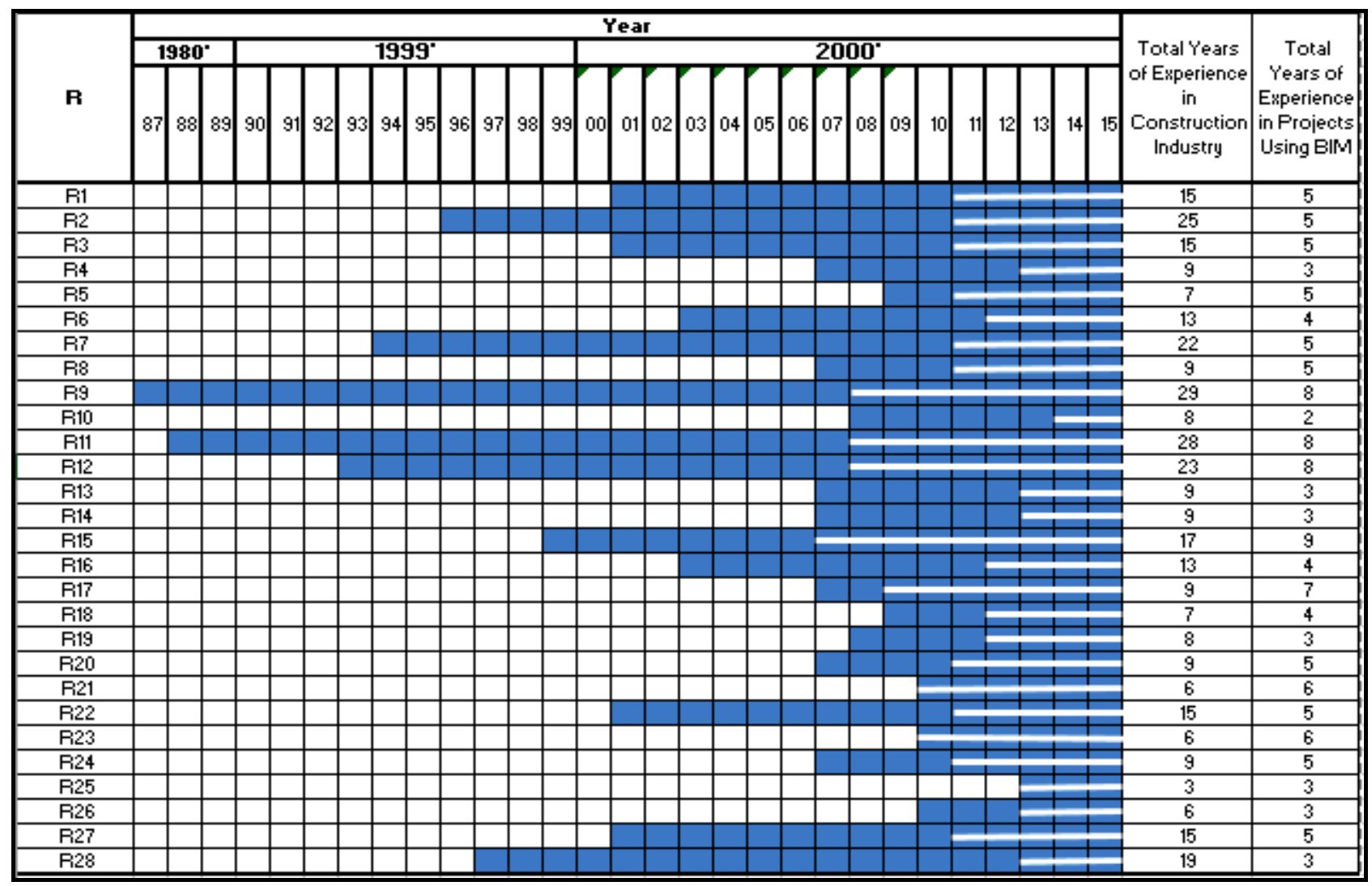

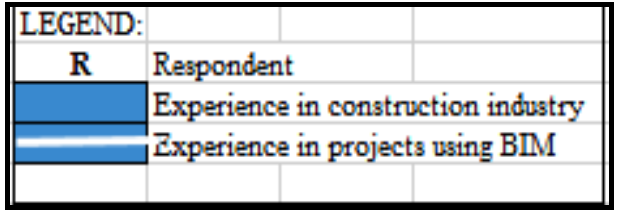

Based on Table 3, from the 28 respondents, only one (1) respondent which is $\mathrm{R} 25$ has experience less than 6 years in the industry. Meanwhile, 15 respondents which are R4, R5, R8, R10 R13, R14, R17, R18, R19, R20, R21, R23, $\mathrm{R} 24, \mathrm{R} 25,26$, have 6 to 10 years of experience in industry. Other than that, 6 respondents which are R1, R2, R6, R16, $\mathrm{R} 22$, R27, have 11 to 15 years of experience and 2 respondents (R2 and R28) have 16 to 20 years of experience in construction industry. Moreover, two (2) respondents (R7 and R12) and two (2) respondents (R9 and R15) have experience 21 to 25 years of experience and 26 to 30 years of experience in construction industry respectively. Most of the respondents have experience for more than 5 years which is it is sensible to infer that the majority of respondents have a sound of knowledge in construction projects and familiar with the conventional construction process a suggested by [28].

Apart from that, twenty one (21) respondents which are R1, R2, R3, R4, R5, R6, R7, R8, R10, R13, R14, R16, R18, R19, R20, R22, R24, R25, R26, R27, R28 have less than 6 years of experience in projects using BIM, while 7 respondents which are R9, R11, R12 R15, R17, R21, R23 have 6 to 10 years' experience in projects using BIM. The respondents that have experience more than 5 years in projects using BIM could be considered as sufficient experience and were familiar with issues at hand as suggested by [28]. Based on the experience of respondents in project using BIM, it showed that the respondents have started using BIM since 2007. Similarly, [18] and [4] also stated that PWD has establish BIM committee to support BIM implementation in the Malaysian construction industry in 2007.

\subsection{Involvement in Project Using BIM}

The involvement of all respondents in projects using BIM is due to several factors. Based on the interviews, there are two reasons of respondents' involvement in projects using BIM. Table 4 shows the involvement of respondents in projects using BIM. 
Table 4. Involvement of Respondents in Projects using BIM

\begin{tabular}{|c|c|c|}
\hline \multirow[b]{2}{*}{ Respondent } & \multicolumn{2}{|c|}{ Involvement in Projects Using BIM } \\
\hline & $\begin{array}{c}\text { Client" } \\
\text { Requirement }\end{array}$ & Own Initiative \\
\hline Ri1 & & $\bullet$ \\
\hline $\mathrm{Fi} 2$ & - & \\
\hline $\mathrm{R} 3$ & $\bullet$ & \\
\hline R4 & $\bullet$ & \\
\hline $\mathrm{R} 5$ & & $\bullet$ \\
\hline Fi6 & $\bullet$ & \\
\hline $\mathrm{R} 7$ & $\bullet$ & \\
\hline $\mathrm{R} 8$ & $\bullet$ & \\
\hline R9 & $\bullet$ & \\
\hline Fio & $\bullet$ & \\
\hline Ri11 & & $\bullet$ \\
\hline Fi12 & & $\bullet$ \\
\hline Ri3 & & $\bullet$ \\
\hline Fi14 & & $\bullet$ \\
\hline Ri15 & & $\bullet$ \\
\hline Ri16 & - & \\
\hline Ri17 & $\bullet$ & \\
\hline Fi18 & $\bullet$ & \\
\hline Ris & $\bullet$ & \\
\hline $\mathrm{Ri} 20$ & & $\bullet$ \\
\hline $\mathrm{R} 21$ & - & \\
\hline $\mathrm{R} 22$ & & $\bullet$ \\
\hline $\mathrm{Ri23}$ & & $\bullet$ \\
\hline $\mathrm{R} 24$ & $\bullet$ & \\
\hline $\mathrm{R} 25$ & & $\bullet$ \\
\hline $\mathrm{Ri} 26$ & & $\bullet$ \\
\hline $\mathrm{R} 27$ & & - \\
\hline $\mathrm{R} 28$ & - & \\
\hline Total & 15 & 13 \\
\hline
\end{tabular}

Based on the table, 15 respondents (R2, R3, R4, R6, R7, R8, R9, R10, R16, R17, R18, R19, R21, R24, R28) were involved in projects using BIM due to requirement by client. Meanwhile, 13 respondents (R1, R5, R11, R12, R13, R14, $\mathrm{R} 15, \mathrm{R} 20, \mathrm{R} 22, \mathrm{R} 23, \mathrm{R} 25, \mathrm{R} 26, \mathrm{R} 27)$ were involved in projects using BIM because of their own initiatives to adopt new technology and process in construction projects. The respondents explained that, client use BIM for the purpose to reduce project' duration, to control project' cost and to improve the quality of project. This is in line with [5] and [6], in their opinion that BIM could improve whole life projects cost, control project time by having faster and effective process and better quality. The respondents that used BIM due to client requirement stated that the implementation of BIM in Malaysia is mainly driven by the encouragement and demand by the client. For an instance, PROKOM has been piloting the use of BIM in their pilot project which is National Cancer Institute (NCI) [4]. Consequence to that, this has encouraged the use of BIM in the next projects funded by the public sector.

On the other hand, the respondents that used BIM due to their own initiative explained that the use BIM could improve their efficiency and productivity in producing projects' design. Hence, they initiate themselves by starting to invest for BIM technology, and getting expertise for training regarding BIM process. Furthermore, this shows that they have their own initiative to support government policy and the needs to adapt BIM in projects. Moreover, the use of BIM by their own initiative is also due to the establishment of PWD BIM Roadmap that made BIM as a compulsory for design and build projects and conventional projects based on contract values [29].

All respondents also highlighted that the implementation of BIM is depending on BIM uses in projects. The next section will discuss on the BIM uses that has been used in Malaysian construction projects.

\subsection{BIM Uses in Construction Projects}

To identify level of BIM implementation in the BIM Malaysian construction industry, each of the respondents have been interviewed regarding BIM uses in the projects using BIM. Table 5 shows BIM uses in the Malaysian construction industry.

Table 5. BIM Uses in Malaysian Construction Projects

\begin{tabular}{|c|c|c|c|c|c|}
\hline \multirow[b]{2}{*}{ Respondent } & \multicolumn{5}{|c|}{ BIM Uses } \\
\hline & $\begin{array}{c}\text { Projects } \\
\text { Visualisation }\end{array}$ & $\begin{array}{c}\text { Improve } \\
\text { Project } \\
\text { Design }\end{array}$ & \begin{tabular}{|l|} 
Detect \\
Design \\
Clashes
\end{tabular} & $\begin{array}{l}\text { Quantity } \\
\text { Take Off }\end{array}$ & $\begin{array}{c}\text { Operation and } \\
\text { Maintenance } \\
\text { of Building }\end{array}$ \\
\hline Ri & $\bullet$ & $\bullet$ & $\bullet$ & & \\
\hline R2 & $\bullet$ & & $\bullet$ & & \\
\hline $\mathrm{R} 3$ & $\bullet$ & $\bullet$ & $\bullet$ & & \\
\hline $\mathrm{R} 4$ & $\bullet$ & $\bullet$ & $\bullet$ & & \\
\hline R5 & $\bullet$ & & $\bullet$ & & \\
\hline Ri6 & & & & $\bullet$ & \\
\hline R7 & $\bullet$ & & $\bullet$ & & \\
\hline 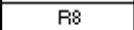 & $\bullet$ & & $\bullet$ & & \\
\hline R9 & $\bullet$ & $\bullet$ & $\bullet$ & & \\
\hline $\mathrm{R} 10$ & $\bullet$ & $\bullet$ & $\bullet$ & & \\
\hline R11 & & & & & $\bullet$ \\
\hline Ri12 & 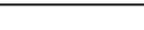 & & 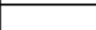 & & $\bullet$ \\
\hline Ri3 & $\bullet$ & $\bullet$ & $\bullet$ & & \\
\hline Ri4 & $\bullet$ & $\bullet$ & $\bullet$ & & \\
\hline Ri15 & $\bullet$ & $\bullet$ & $\bullet$ & & \\
\hline Ri6 & $\bullet$ & $\bullet$ & $\bullet$ & & \\
\hline Ri17 & $\bullet$ & $\bullet$ & $\bullet$ & & \\
\hline Ri18 & $\bullet$ & $\bullet$ & $\bullet$ & & \\
\hline Ri19 & $\bullet$ & $\bullet$ & $\bullet$ & & \\
\hline $\mathrm{R} 20$ & $\bullet$ & $\bullet$ & $\bullet$ & & \\
\hline R21 & $\bullet$ & $\bullet$ & $\bullet$ & & \\
\hline Ri22 & $\bullet$ & $\bullet$ & $\bullet$ & & \\
\hline Ri23 & $\bullet$ & & $\bullet$ & & \\
\hline Ri24 & $\bullet$ & $\bullet$ & $\bullet$ & & \\
\hline Ri25 & $\bullet$ & $\bullet$ & $\bullet$ & & \\
\hline R 26 & $\bullet$ & & & & \\
\hline $\mathrm{R} 27$ & $\bullet$ & $\bullet$ & $\bullet$ & $\bullet$ & \\
\hline $\mathrm{R} 28$ & $\bullet$ & $\bullet$ & $\bullet$ & & \\
\hline Total & 25 & 19 & 24 & 2 & 2 \\
\hline
\end{tabular}

There are five (5) BIM uses that being implemented in projects using BIM as shown in the table. They are to improve projects visualisation, improve project design, detect design clashes, quantity takeoff, and operation operation and maintenance of building. From the table, twenty five (25) of respondents have experienced using BIM for projects visualisation. The respondents pointed out that BIM is used to help client to visualise the completed projects as early in pre-construction phase. BIM also helps other construction players such as architect, $C \& S$ and $M \& E$ engineer to visualise on the design effectively so that they can detect any discrepancies between trades.

Meanwhile, nineteen (19) of the respondents experienced using BIM in projects for improving projects design. The respondents explained that, they used BIM to develop projects design in $3 \mathrm{D}$ model with projects' information in effective and more efficient so that they could avoid any discrepancies. As [5] and [15] claimed that, BIM helps construction players to have better design with less error. Also, the 3D models capable to show construction players the location of buildings in the future environment and also gives the project's end users an insight into the development of an area.

Moreover, twenty four (24) of respondents have experienced in using BIM for detecting design clashes. From the interview, the respondents that involved as M\&E 
engineer stated that their is still new in projects using BIM. Nevertheless, they also added that, the involvement of M\&E engineer in projects using BIM is more crucial due to the compelexity of the design and its element. So that, $M \& E$ engineer could produce drawing, installing $M \& E$ system in more accurate [30]. All respondent also claimed that the involvement of C\&S engineer together with $\mathrm{M} \& \mathrm{E}$ engineer are most practical as they could detect any possible clashes between three trades (architect, $C \& S$ engineer and $M \& E$ engineer).

Meanwhile, only two (2) of respondents experienced using BIM for quantity take off. The respondents explained that, BIM helps to generate the quantity in more accurate and efficient. The use of BIM for quantity take off furnishes great potential to make cost prediction above the limitation posed by traditional method [31]. However, the respondents explained that the use of BIM specifically for quantity take off is still new and required cooperation with architects to develop 3D model followed by QS specification. Moreover, only two (2) respondents used BIM specific in postconstruction phase. The respondent use BIM to maintain the operation and maintenance of the completed projects by remodel $2 \mathrm{D}$ as-build drawing to $3 \mathrm{D}$ model with necessary data. The information in the building model is associated with spaces, masses, construction level details and scope of the model (such as architectural and details of MEP elements) [15]. In addition to that, the respondents higlighted that, the use of BIM for maintenance and operation of building is done only after the projects has completed in conventional practices.

From the data collected, the implementation of BIM in Malaysia still at infant stage. This is in line with research by [13] and [32] as the implementation of BIM in Malaysia still in early phase of inception and far behind from other developed countries. In addition to that, most of the respondents stated that they have experienced in handling only one (1) projects using BIM and still in learning and

\section{References}

1. D. Bryde, M. Broquetas, and J.M. Volm. The Project Benefits of Building Information Modelling (BIM). International Journal of Project Management, 31(7), 971-980. (2013)

2. A. Ahmad Latiffi, J. Brahim, S. Mohd, and M.S. Fathi. The Development of Building Information Modelling (BIM) Definition. Applied Mechanics \& Materials, (567). (2014)

3. S. Azhar. Building Information Modeling (BIM): Trends, Benefits, Risks, and Challenges for the AEC Industry. Leadership and Management in Engineering. (2011)

4. PWD. Unit Building Information Modelling (BIM). Retrieve from: https://www.jkr.gov.my/prokom/ind ex.php?optioncom_content\&view=article\&id=84\&It emid=435\&lang=ms. (2011)

5. S. Azhar, M. Khalfan, and T. Maqsood T. Building Information Modelling (BIM): Now and Beyond. Australasian Journal of Construction Economics and Building, 12(4), 15-28. (2012) training period. Further to that, the implementation of BIM is still limited at pre-construction phase. Only two respondents (R11, R12) used BIM specific at postconstruction phase. It also suggested that the implementation of BIM in the Malaysian construction industry need to be more strategised to ensure the implementation of BIM from pre-construction phase to postconstruction phase. The respondents suggested that to ensure the improvement and continuous of BIM implementation, it is not only depends on the use of BIM technology, it is also depending on the competencies of construction players in understanding the process involved. This is because, the use of BIM also depending on the size and capabilities of the organisation to invest new technology [13].

\section{Conclusion and Further Works}

Undoubtedly, Malaysian construction industry aware of the needs to adopt BIM technology in improving current construction projects. Still, it shows that the Malaysian construction industry need to have better strategies in highlighting and embracing the use of BIM from preconstruction phase to post-construction phase. Further works will be conducted on the construction players' current practices in projects using BIM.

\section{Acknowledgement}

The authors would like to thank to Ministry of Higher Education of Malaysia (MOHE), and Office of Research, Innovation, Commercialization and Consultancy (ORRIC), UTHM for supporting this research under the Exploratory Research Grant Scheme (ERGS), (Vote No. E029).

6. R. Eadie, M. Browne, H. Odeyinka, C. McKeown, and S. McNiff. A Survey of Current Status of and Perceived Changes Required for BIM Adoption in the UK. Built Environment Project and Asset Management, 5(1), 4-21. (2015)

7. A.K.D, Wong, F.K.W. Wong, and A. Nadeem. Government Roles in Implementing Building Information Modelling Systems: Comparison Between Hong Kong and the United States. Construction Innovation, 11(1), 61-76. (2011)

8. M. Dobelis. Drawbacks of BIM (Building Information Modelling) Concept Adoption. Paper presented at the International Conference: Enginering Graphics BALTGRAF 2013, 12, Riga (Latvia), 5-7 Jun 2013. (2013)

9. R. Barati, A. Charehzehi, and C.N. Preece. Enhancing Planning and Scheduling Program by using Benefits of BIM-based Applications. Civil and Environmental Research, 3(5), 41-48. (2013)

10. W. Kymmell. Building Information Modeling: Planning and Managing Construction Projects with 4D CAD and Simulations (McGraw-Hill Construction Series): Planning and Managing Construction Projects with 4D CAD and Simulations: McGraw Hill Professional. (2008) 
11. R. Volk, J. Stengel and F. Schultmann. Building Information Modeling (BIM) for Existing BuildingsLiterature Review and Future Needs. Automation in Construction, 38, 109-127. (2014)

12. C. Furneaux and R. Kivit. BIM: Implication for Government. CRC for Construction Innovation. Brisbane Australia. Pp. 10-3. (2008)

13. Z. Zakaria, N. Mohamed Ali, A. Tarmizi Haron, A.J. Marshall-Ponting, and Z. Abd Hamid. Exploring The Adoption of Building Information Modelling (BIM) in the Malaysian Construction Industry: A Qualitative Approach. International Journal of Research in Engineering and Technology, 2(8), 384395. (2013)

14. S.S.S. Gardezi, N. Shafiq, and M.F. Khamidi. Prospects of Building Information Modeling (BIM) in Malaysian Construction Industry as Conflict Resolution Tool. Journal of Energy Technologies and Policy, 3(11), 346-350. (2013)

15. C. Eastman, P. Teicholz, and R. Sacks. BIM Handbook: A Guide to Building Information Modeling for Owners, Managers, Designers, Engineers and Contractors John Wiley \& Sons. (2011)

16. K.P. Reddy. BIM for Building Owners and Developers: Making a Business Case for Using BIM on Projects. John Wiley \& Sons. New Jersey. (2012)

17. M. Jaafar, T. Ramayah, A. Abdul-Aziz, and B. Saad. Technology Readiness among Managers of Malaysian Construction Firms. Engineering, Construction and Architectural Management, 14(2), 180-191. (2007)

18. A. Ahmad Latiffi, S. Mohd, N. Kasim, and M.S. Fathi. Building Information Modeling (BIM) Application in Malaysian Construction Industry. International Journal of Construction Engineering and Management, 2(A), 1-6. (2013)

19. G. Sundaraj. The Way Forward: Construction Industry Master Plan 2006-2015. Master Builder, $1^{\text {st }}$ Quarter 2007. Retrieved from: http://woulibrary.wou.edu.my/library/pdf/CIMPlan.p df. (2006)

20. Construction Industry Development Board (CIDB). BIM Portal: Building Information Modelling. Retrieve from http://bimcenter.com.my/index.php/ bim-news. (2013)

21. CIDB. Construction Industry Transformation Programmes 2016-2020. Retrieved from: file://C:/Users/User/Downloads/CITP-public.pdf. (2015)

22. Construction Research Institute of Malaysia (CREAM). Issues and Challenges in Implementing Building Information Modelling (BIM) by SME's in the Construction Industry. Retrieved from:https://www.cidb.gov.my/cidbv4/images/pdf/an nouncement/BIM/bim $\% 20$ seminar $\% 20 \% 20$ worksho p \%20for\%20malaysia\%20construction $\% 20$ industry. pdf. (2014)

23. Jabatan Kerja Raya. Garis Panduan BIM JKR: Edisi 2014. Kuala Lumpur. Jabatan Kerja Raya. (2014)
24. R. Crotty. The Impact of Building Information Modelling: Transforming Construction. Routledge. (2013)

25. M. Saunders, P. Lewis and A. Thornhill. Research Methods for Business Students: Fifth Edition. Pearson Education Limited. Edinburgh Gate. (2009)

26. R. M. Nordin. A Framework of Transperancy Initiatives to Fight Corruption for Public Construction Projetcs. Thesis. Universiti Teknologi Mara. Malaysia. (2015)

27. M. B. Barison, and E. T. Santos. An overview of BIM specialists. Computing in Civil and Building Engineering, Proceedings of the ICCCBE2010, 141. (2010)

28. S. H. Hamid. An Integrated of Value Management (IVM) Framework for Contractor in Design and Build (D\&B) Project. Unpublished Msc Thesis. Universiti Teknologi Mara. (2014)

29. Q.C. Keat. What It Will Take To Ensure 5D BIM Sustainability in Malaysia. Retrieved from: https://www.academia.edu/4929524/What_It_Will_T ake_To_Ensure_5D_BIMSustainability_In_M̄Malaysia . $(2013)$

30. C.S. Dossick, and G. Neff. Messy Talk and Clean Technology: Communication, Problem-Solving and Collaboration using Building Information Modelling. The Engineering Project Organization Journal, 1(2), 83-93. (2011)

31. N.A. Ismail, E. Utiome, R. Owen and R. Drogemuller. Exploring Accuracy Factors in Cost Estimating Practice towards Implementing Building Information Modelling (BIM). Paper presented at the Proceedings of the 6th International Conference On Engineering, Project, and Production Management (EPPM2015).(2015)

32. N.A.H. Hadzaman, R. Takim and A.H. Nawawi. BIM Roadmap Strategic Implementation Plan: Lesson Learnt From Australia, Singapore and Hong Kong. Proceedings in 31st Annual ARCOM Conference. 611-620. (2015) 